\title{
Religion, Suffering and Female Heroism: Transformations in the Meaning of Sacrifice in a Catholic Conversion Movement
}

\author{
Marjet Derks
}

Introduction

We are an international movement and community of women of different cultures, social backgrounds and generations. We trust in the Spirit of God, Mystery and Source of Life. We are called to create a sustainable world, transforming our planet into a place of peace and justice. We acknowledge that we are part of the whole of creation, striving to live simply and to nurture a culture of care for all the earth. We are determined to look for signs of hope in a complex world. We are strengthened by the compassionate energy and creative action of women. ${ }^{1}$

Anyone visiting the website of the International Grail comes across these words encapsulating the current vision of this women's movement. The Grail is a spiritual, social and cultural movement "grounded in Christian faith" that through working in different cultures seeks to work for justice and peace and to enable women to develop their full potential. It is active in eighteen countries and is recognized by the United Nations as a Non-Governmental Organization with a special consultative status in relation to women within the UN Economic and Social Council. The Dutch branch - the movement's first one, established in 1921 - explicitly states that its common ground is:

[T] o find meaningful ways of expressing our spirituality in action. The Grail movement in the Netherlands has grown into a community where a lively and exciting exploration is taking place in feminist theology, Christianity and Zen Buddhism. ${ }^{2}$

1 “The vision of the Grail," see www.thegrail.org. The women's movement of the Grail should be distinguished from another movement of the same name. The latter is a so-called new religious movement that originated in Germany in the late 1940 s and is inspired by the work of Oskar Ernst Bernhardt (see www.grailmessage.com).

2 www.degraalbeweging.nl. 
The Grail websites present an international movement of modern women who, inspired by a range of both religious and secular thinkers, want to play an active role in today's world. If anything, the visual culture of the Grail is dominated by words and images that, in addition to female bonding, reflect self-awareness, confidence and autonomy. Nothing could be further removed from concepts of sacrifice and suffering.

Nevertheless, a sacrificial culture originally lay at the core of the movement and for decades was fundamental to its spirituality. This fact has been erased from memory and, consequently, from history. Instead of regarding this as a mere historical error, I argue that it is rather an indication of the basically historical nature of the concept of sacrifice. By this I mean that its societal, cultural and spiritual-theological qualifications are related to specific historical contexts. The meaning and the assessment of the concepts of sacrifice and, consequently, of personal suffering change throughout history and are therefore variable concepts. While certain sacrificial acts were highly valued in a specific time and age, the same acts could be perceived as degrading in another. Whereas different cultural understandings of sacrifice are usually taken into account, historical ones often are not. Consequently, it remains unacknowledged that what once was regarded as an outstanding virtue could later become an unwanted - and eventually even purposely forgotten or denounced - heritage. So, instead of looking at sacrifice from an anthropological or psychological perspective, I perceive sacrifice as an object of cultural history and try to grasp its meaning in a specific historical context. ${ }^{3}$

Furthermore, I take gender into account. My analysis starts from the assumption that, culturally and socially, different sacrificial roles are attached to, and expected from, men and women. This versatile attitude towards sacrifice seems particularly present when women are concerned, because concepts of both gender and sacrifice appear to have changed considerably over time. It is vital to acknowledge the complex historical importance of sacrifice for women in the religious realm, because it is here that both the attractive and repressive sides of religious movements align. This means that in order to understand the current emphasis on female autonomy mentioned above, we have to look at the enforced, yet willing submission of these women in the past.

3 For another historical, yet essentially psychological approach of the meaning of sacrifice in a Catholic context see Emke Bosgraaf, Gebroken wil, verstorven vlees. Een historischpsychologische studie over versterving in het Nederlandse kloosterleven,1950-1970 (Groningen: Facilitair Bedrijf/Grafimedia, 2009). 
This article elaborates on the rise of the Grail's sacrificial culture in the pre-war period and its gradual disappearance from the 1960s onwards. Firstly, the rise of the Women of Nazareth will be typified: A group of intellectual lay women that became the leadership of the Grail movement. An ambiguous sacrificial culture was essential for this movement: Although it was intended as a means of individual submission and of shaping a community with a collective purpose, sacrifice actually functioned as an instrument creating individual excellence and non-vocalized group hierarchy. Self-imposed penances and acts of mortification were not only identity markers, but through these practices the women aimed at becoming co-saviors, contributing to diminishing the sins of the world. Their being co-saviors was meaningful on an individual as well as a collective level.

And last but not least, these practices served on various levels as a disciplinary instrument. They enabled the Jesuit leader to keep control over the women, allowed individual women mastery of themselves, and they installed hierarchical cliques within the group. Yet it was only through excellence in sacrifice that women could engage in religious heroism. Thus, sacrifice became a source of repression and of mutual competition. All this should be understood against the historical background of the aftermath of World War I in general, and the position of women in the religious realm in particular. The second part of the article focuses on the process within which this heritage has been erased from the collective memory of the Grail since the 196os.

\section{$2 \quad$ "Woman's Natural Capacity for Sacrifice and Suffering." The Origins of the Grail Movement}

The aftermath of World War I initiated moral concern amongst an internationally oriented group of Catholic intellectuals, writers and artists in the transatlantic area. Among those were a considerable number of converts, such as the French thinkers Léon Bloy, Jacques Maritain and his wife Raïssa, and the English writer G. K. Chesterton. They evaluated the cultural and moral dismantling of the western world as basically a religious problem caused by modernity, and aimed at a Catholic revival by placing the Mother Church once again at the centre of western intellectual life. ${ }^{4}$ Inspiration was sought and found not

4 Paul Luykx, "Daar is nog, poëzie, nog kleur, nog warmte." Katholieke bekeerlingen en moderniteit in Nederland, 1880-1960 (Hilversum: Verloren, 2007); Patrick Allitt, Catholic converts. British and American intellectuals turn to Rome (Ithaca, London: Cornell University Press, 1997). 
only in the writings of another famous convert, namely the English Cardinal John Henry Newman, but also in Catholic tradition. Although a diverse group of cultural critics, many of these intellectuals idealized the vigor of early Christianity and the mysticism of the Middle Ages. They were especially fascinated by monastic traditions of asceticism and physical penances. Because of the allure that suffering had for them, they often cultivated such practices themselves, regarding them as the articulation of a counter-pressure against secularization and a way of participating in the suffering of Jesus. ${ }^{5}$

\subsection{Victim Spirituality}

In fact, the whole period of the interwar years showed a remarkable rise in the popularity of a phenomenon that had made a first re-appearance in nineteenth-century France: The so-called 'victim-souls'. These were people who, in their own perception or that of others, were specially chosen by God to suffer more than most people during their lifetime. They generously and willingly accepted the suffering because it signified a union with their Savior: Their actions were inspired by Christ's own Passion and death. Behind this willful embrace of sacrifice and suffering lay a desire to make reparation for the sins of mankind. Being deprived of other social, cultural or religious means to participate in the history of salvation - since this was the exclusive prerogative of the ordained priesthood - women particularly identified with these practices of spiritual repair. These practices provided the desired participation in salvation, albeit in a complex manner, in which submission and feelings of exclusivism became intertwined. 6 "A self-appointed religious elite", the historian Richard Burton has aptly typified them. ${ }^{7}$ This elite felt re-enforced and approved by Church politics of canonization, since both Jeanne d'Arc and Anna Maria Taigi were canonized in 1920 . The former was a symbol of female pious persistency

5 For the French susceptibility to this cultural and religious climate see Brenna Moore, Sacred Dread: Raïss Maritain, the Allure of Suffering, and the French Catholic Revival (1905-1945) (Notre Dame: University of Notre Dame Press, 2013); Stephen Schloesser,Jazz-Age Catholicism. Mystic Modernism in Post-war Paris, 1919-1933 (Toronto: University of Toronto Press, 2005).

6 Nancy Jay, "Sacrifice as Remedy for Having Been Born of Woman," in The Female in Sacred Image and Social Reality (ed. Clarissa Atkinson; Boston: Beacon Press, 1985), 283-309 (297-304).

7 Richard Burton, Holy Tears, Holy Blood. Women, Catholicism and the Culture of Suffering in France, 1840-1970 (London: Cornell University Press, 2004). Also: Moore, Sacred Dread; Paula M. Kane, "She offered herself up. The Victim Soul and Victim Spirituality in Catholicism," Church History 71:1 (2002): 80-119; Steffen Lösel, "Prayer, Pain, and Priestly Privilege: Claude Langlois' New Perspective on Thérèse of Lisieux," in Journal of Religion 88, 3 (2008): 273-306; Ida Magli, Women and Self-Sacrifice in the Christian Church. A Cultural History from the First tot the Nineteenth Century (Jefferson, London: MacFarland \& Company, 2003). 
through trials and tribulations, while the latter, a nineteenth-century Italian housewife and mother, was known to have been "a true victim-soul" by leading a life full of prayer, mortification and self-denial. ${ }^{8}$ The canonization of another female apostle of suffering in union with Christ, Gemma Galgani, followed in $1940 .^{9}$

Against this historical background, a Dutch Jesuit, the internationally renowned linguist Jacques van Ginneken, came to develop his own ideal of a profound, vigorous and mythical Catholicism and saw an all-embracing conversion as a countermovement against the growing secularization. In line with other radical Catholics, with whom he held close contact, Van Ginneken constructed his view upon an idealization of early Christianity, the era of the martyrs. He thought that practice of the faith should be passionate and militant. The ascetic movements of the Middle Ages also inspired him because they displayed devotion and suffering for a religious cause. Contrary to his contemporaries, Van Ginneken believed that women, as both militant combatants and devoted sufferers, were most suited for such a new golden age of Catholicism. Women would be 'naturally' enabled to give themselves totally to a higher ideal, and in addition possessed a superior capacity to engage in a "spirituality of the Cross", in which sacrifice and suffering held a special place. He underlined this theory by pointing to several strong women from the history of Christianity, notably in early Christianity and the Middle Ages. By constructing a female genealogy, Van Ginneken provided the means of identification and legitimization for the women that he wanted to gather to save the world. Furthermore, it was not women religious but lay women who should take up this role, because the strict rules and regulations that the Church laid upon convents prevented nuns from carrying out a militant task in the world. ${ }^{10}$

\subsection{Militant Sacrificers: The Women of Nazareth}

To support his cause, the visionary Van Ginneken established two associations of Catholic laywomen: The Ladies of Bethany and the Women of Nazareth. Ahead of what later would become widely known as Catholic Action, they were to become a "quasi-religious nucleus of the lay apostolate". Both groups aimed to convert on a global scale. From a social perspective, the members

$8 \quad$ Nieuwe Tilburgsche Courant, 27-04-1920.

9 Lucietta Scaraffía, "Christianity has liberated her and placed her alongside man in the family: from 1850 to 1988," in Women and Faith: Catholic Religious Life in Italy from Late Antiquity to the Present (eds Lucietta Scaraffía and Gabriella Zarri; Cambridge MA: Cambridge University Press, 1999), 249-280.

10 The following paragraph is based on Marjet Derks, Heilig moeten. Radicaal-katholiek en retro-modern in de jaren twintig en dertig (Hilversum: Verloren, 2007), 188-324. 
were representative of a first generation of highly educated Catholic women who had no desire to take on the accepted ideals of either motherhood or convent life. However, they were very willing to follow a social and religious calling and Van Ginneken's lay associations held a strong appeal.

The Women of Nazareth's goal was the conversion of adolescent city girls, as a starting point for the conversion of this target group in other countries too. After a few years, however, the bishop of the Haarlem diocese, where the group was centered, demanded that they take up responsibility for the ailing Catholic girls' movement. After rigorous deliberation, Van Ginneken and the women decided to comply, making this "sacrifice of obedience", as they referred to it amongst each other. In 1928, they started the so-called Grail movement, and due to its modern approach and appropriation of methods from the youth movement this soon became the largest and most successful youth movement in the Netherlands. Tens of thousands of girls joined, engaging in outdoor activities, taking part in gatherings in special clubhouses, marching the streets in colorful uniforms and performing large scale theatrical religious plays in stadiums. From 1932 onward, the movement began to spread to other countries, first in Western Europe (Germany, England, Scotland and Ireland) and after a while to Australia and the United States.

The movement seemed modern, straightforward and very artistic. The internal dynamics, however, resembled an inverted family-like group, with features of what sociologist Erving Goffman has described as a "total institution"." Becoming a genuine member, and thus justifying the choice of this way of living, involved a process of "mortification of the self", the sacrifice of one's own personality. Grail women remained lay women. Therefore, while working "in the world" they would have to be immune to worldly temptations. This called for subjection to degrading and humiliating treatment, both self-inflicted and imposed by Van Ginneken. In addition, he demanded a regular and detailed update of what had been practiced. To get this, he kept in close contact with the women who led the movement. Without any supervision or control from the outside, these practices were more far-reaching than the penances and acts of mortification that were being practiced in religious orders. In fact, the daily life of the Women of Nazareth was dominated by a much cultivated yet hidden - sacrificial culture of severe physical and mental penances: Practices of joyous suffering within the group. A true member would excel at sacrifice. These practices also served the movement's aim: By becoming a holocaustum (which means "fire sacrifice" and was the term Van Ginneken used),

11 Erving Goffman, Asylums. Essays on the Social Situation of Mental Patients and other Inmates (New York: Doubleday, 1961). 
the women would stand out as purifiers. They would repair the world's wrongdoings and encourage conversion. Through the sacralization of sacrifice, suffering and loss were turned into a source of spiritual power.

\section{3}

\section{Reinventing the Grail in the 196os}

After World War II, things changed on a large scale and at a fast pace. The war years had left the Grail shattered, its houses confiscated by the German occupying force, the girls' movement forbidden, and the leadership dispersed. Contact had been difficult during the war, especially with those Women of Nazareth who lived and worked outside the Netherlands. Lacking in financial means, many Women of Nazareth were forced to take up jobs in totally different fields from the ones they were used to. A relatively large group became nurses, while others found employment in offices or schools. Communal meetings and spiritual retreats became rare, although Van Ginneken, who was forced to go into hiding, did manage to meet with a small group of Grail leaders once in a while. On those occasions, he kept accentuating the importance of the sacrificial spirituality and the cause of world conversion. But by then it had become clear that the type of girls' movement that belonged to the interwar years had outlived its appeal and would not easily be restored after the war. When, in 1946, Van Ginneken died of a brain hemorrhage, the Grail seemed to be finished.

\subsection{Renewal of Christian Culture}

Nevertheless, the so-called Nucleus (central group) of the Women of Nazareth, who after the war had continued under the name of the Grail, did eventually manage to work out a new orientation. The concept of conversion underwent major changes in this new orientation. Engaging itself with the world crisis that now manifested itself, the Grail reappeared with a vision of a renewed Christian culture. A universal perspective and a missionary spirit became key concepts, yet still closely linked to the all-embracing nature of Catholicism. The movement set out to develop a kaleidoscopic range of apostolic endeavors to advance what was now called "spiritual conversion", ranging from work among poor neighborhoods and students in the Us to the development of a world-wide missionary movement. ${ }^{12}$

12 Alden V. Brown, “The Grail Movement to 1962: Laywomen and a New Christendom," U.S. Catholic Historian 3, 3 (1983): 149-166. 
Primarily, the new Grail became an international movement that aimed at training young women to work as lay missionaries in education and health care and to catechize all over the world. Already in 1947, the Tiltenberg, the movement's mother-house, had become a mission school attended by dozens of young women who were eager to work as missionaries but felt no attraction whatsoever to becoming nuns. None other than the Dutch Prime Minister Beel opened the school and applauded its existence. A year later, the school moved to a reconstructed house in Ubbergen (near Nijmegen). ${ }^{13}$ The successful reorientation of the Grail attracted hundreds of young women who spread the organization's work in an increasing number of countries. It made the Grail even more of an international movement than it had been before the war. Although there were some generational differences within the movement, its success seemed to compensate for that.

\subsection{In Search of New Concepts of Identity}

Success and growth seemed to imply that the Grail's approach to Christian cultural renewal was seen as valid, but this was only partly true. The newstyle Grail had to deal with a world that was rapidly changing, politically as well as socially, economically, and technologically. This affected its religious setting to a great extent. While the number of people leaving organized religion was growing, the Catholic Church experienced an increasing influence of modern theologians. Throughout the 1950s, these theologians began to turn away from the neo-Thomism and anti-modernism that had been dominant since the nineteenth century and began to address relations between the Church and the modern world. They pleaded for the integration of modern human experience with the principles of a Church based on Jesus Christ, and for re-engagement with the Scripture and with the Church Fathers as a basis for renewal. It was these reflections and deliberations that led to the Second Vatican Council (1962-1965), in which various Grail women were actively involved, both as translators, hostesses and auditors. ${ }^{14}$ Although the Grail unambiguously supported the Council's conceptualization of aggiornamento, they did not immediately grasp the consequences it would have for them. The conciliar call for a new orientation on both the present and the past had an enormous impact on the Grail movement, which had just been theologically retuned.

\footnotetext{
13 Limburgs Dagblad (November 8, 1947 and April 22, 1948).

14 Marjet Derks, "Changing Lanes: Dutch Women Witnessing the Second Vatican Council," Trajecta. Religion, Culture and Society in the Low Countries 22, 1 (2013): 81-102.
} 
As far as the present was concerned, the Grail felt forced to discuss the lay status that had been the core of its identity since the creation of the Women of Nazareth. The Decree Perfectae Caritatis, on the adaptation and renewal of religious life, stated that all members of religious orders were in fact lay people and should be regarded as such. In this way, nuns became competitors to the Grail women who had always cherished their lay status and wanted fervently to distinguish themselves from women religious. Despite the renewal that was going on in the religious orders, the Grail women felt that nuns would never understand the world in the way that they did. A member of the Nucleus wrote in 1963:

[W]e need an approach to our world that has much more real contact with the kind of world in which we are living. The nuns do not have this and I doubt, even with many changes, if they can achieve it. ${ }^{15}$

Consequently, the Grail women felt the need to re-conceptualize their identity as well as rethink the needs of modern life to which they should adapt. In other words, once again, the Grail needed to reinvent itself. In several national and international conferences, the movement opted to open itself to women from all kinds of spiritual backgrounds, and began to focus more strongly on social, political and economic justice. This was reflected in a changing vocabulary, from which phrases such as "integral Catholicism" or "new Christendom" disappeared altogether. ${ }^{16}$

\section{4} Evaluating the Sacrificial Past

Much more difficult, and according to historian Alden Brown even 'agonizing', was the long process of self-criticism in which the past was re-examined. The Grail felt that it, too, was addressed by the Council's urging religious orders to engage in a program of ressourcement in order to determine what needed to be changed so that they could better accord with the spirit of their founders. The Nucleus set out the results of a thorough research of Van Ginneken's original aim and spiritual assumptions. This included his perception of the spirituality of the Cross, which had held such a central place in the militant Catholic

\footnotetext{
15 Archives of the International Grail, nr. 53: letter of Mary Imelda Buckley to Dolores Brien (July 1963).

16 Brown, "The Grail Movement," 164-165.
} 
interwar years but now seemed hardly compatible with Vatican and theological renewal.

\subsection{Personal Images of the Cross}

In 1964, the Nucleus of the Grail decided it was time for a written consultation with all its members. This consisted of 33 questions that were divided into several sub questions. A total of 148 Grail women ( 77 individuals and 71 group participants) sent in their answers. ${ }^{17}$ One of the key questions of the consultation addressed the theme of the spirituality of the Cross, referring to the spirituality of suffering and sacrifice on which Van Ginneken had continually placed so much emphasis. "How do you see the place of the Cross in your life?", was the first sub question, to which some women filled in more than one answer.

The answers were quite revealing. A substantial group of respondents attached positive meanings to the Cross. Fourteen respondents, in particular older members, stated that it was central in their lives. "To my generation (25 years ago) it was very involving to accept and propagate the Cross in a feminine way", one member wrote. Ten women answered that, for them, it represented a participation in redemption.

For 26 women, the Cross did not refer to a 'thing', but rather was an attitude and a day-to-day reality which came from God. As one of them stated: "[I]t is a training to live in the spirit of the Gospel and to keep being directed towards God".

Five respondents said it meant the joyful acceptance of daily difficulties and disappointments; eight members saw it as union with Christ and one even as the climax of Incarnation. Fourteen said that it was a source of life and even consolation to them, eleven that it represented the obedience of surrender to God, and six that it held purifying qualities.

For a much larger group, however, the Cross held merely negative connotations. Three respondents stated that it caused tensions about what they were and should do; sixteen women said that their temperament hindered the demands of sacrifice; two explicitly said that it made them lonely; two that it added to their sense of aging.

One Grail woman stated that she felt the culture of sacrifice had brought her into confrontation with the unpredictable whims of her flesh and emotions, while another said she felt exposed to her state of being unredeemed.

A large group of Grail women responded that they experienced the Cross mostly in relationships with other Grail members (community life), or people 
they had to work with, or in having to confront a changing world or their own aging process. They did not need any additional suffering, as coping with all this was difficult enough:

As I grow older, I have come to realize that the cross exists in the acceptance of everything that life holds in store: Old age, sickness, and everything that accompanies those processes.

One of the former leading Women of Nazareth was of the same opinion. She believed that in the past, the Cross had been "looked for":

I believe that spiritual growth will, as a rule, be promoted rather through the circumstances of life itself than through things of our own finding.

One Grail woman wrote as a comment:

I have never been inspired by the idea of looking for the Cross, not because this is difficult and painful, but because I believe that we should be humble and ready to accept what He sends us, we must leave it to Him whether to send us comfort or pain, and we must trust that He will help us.

The responses made it clear that the spirituality of suffering and sacrifice no longer held the place it used to. The answers were quite diverse and did not unequivocally point in the same direction. For some respondents the cross held a very positive quality, while others referred to it as a source of loneliness, cutting them off from the community. Some seemed to give it a very central position, while others wanted to minimize it.

\subsection{Personal Images of Mortification}

The second part of the question was even more revealing. It addressed the theme of personal mortification: "How do you understand the relation of mortification and penance as we have practiced them to your present circumstances?". It was answered by 56 individual Grail members and 74 participants in groups. The way the question was formulated led some women to give their evaluation of the "old forms" of penance. Again, sometimes more than one answer was given.

Eighteen respondents stated that the past forms of penance and mortification had been helpful and meaningful. For two of them, they had given a certain discipline and helped to free them up for higher goals: 
I understand the relation of mortification and penance as follows: Mortification is the giving up of egoism and turning towards Christ, penance is for me the reparation of my personal sins and the sins of others. The relation is the complete trust in God's mercy.

Two women said that it had helped them to surrender to God or to feel one with the Church or the group. One of them did add, however, that she no longer performed any penances like the ones she used to "because I am just not strong enough for that (physically!)", thus implying how hard these practices had in fact been. Two others stated explicitly that they loved what they described as "these symbols of religious extremism". They expressed their desire that corporal penances would remain, albeit as a matter of personal choice.

Several explicitly named fasting and waking as 'authentic' and therefore desirable forms of penance - provided they could be done voluntarily, not on demand - while at the same time rejecting other forms that had prevailed in the past.

On the other hand, 41 women said that none of the penances and acts of mortification had been helpful or meaningful at all. Three said that they had hindered their growth to maturity, and that they certainly had not helped them to acquire any sense of responsibility. For two, they were not at the heart of Christian living and charity did not grow because of it.

Thirteen women stated that the mortification had been artificial, too extreme, isolated acts and separate from real life. Three said that the acts of mortification had made one concentrate too much on oneself and had been a hindrance to contact with others, thus blocking rather than stimulating any sense of community.

Three respondents even said that the acts of mortifications had intensified conflicts and pressures, while for two women they had been unhealthy and caused nervous breakdowns. One respondent made it clear that the mortification held the danger of conformity, while another woman said that they had an ambiguous flavor of pain-seeking. Four respondents explicitly stated that the penances had been merely a means of personal achievement, done in order to be perfect or to be in control of oneself.

Several women explicitly warned that mortification and penances had even been a source of wanting to perform and excel: "The danger of wanting to excel was very great", one woman stated, and another said:

I, personally, find this a dangerous method because it easily degenerates into a desire for achievements. It also creates unnecessary tensions in our life which already has more than enough tensions without these 
additional ones. In relation to my present circumstances these practices appear rather childish.

From this period onward the sacrificial culture became a matter of personal choice, a practice mainly for the older generation, which was tolerated, but not applauded. The Grail's self-perception gradually aligned with the feminism of the feminist theological tradition. Books written by Grail women about the movement's past stressed that it had originated as a women's and a lay movement, and, moreover, as an ecumenical movement. ${ }^{18}$ In 1985 , it was even claimed that as far back as the 1920 s their predecessors had been driven through and through by a feminist approach. By now, even older members, such as Lydwine van Kersbergen, who had been one of the Grail leaders in the interwar period, one of Van Ginneken's most intimate confidants and a fierce defender of the sacrificial culture, declared that the Women of Nazareth had been the beginning of women's liberation: "No authority from outside". 19

The process of feminizing the Grail's history came to a height in the volume Dangerously modern, published in 2001, where it says that Grail women had been the prototypes of the proverbial "strong woman": Emancipated, renewing and autonomous. ${ }^{20}$ The word 'sacrifice' did not come up once in any of these histories. In fact, when a television documentary on the Grail was made in 1982, in which a former member did refer to the penances and acts of mortification, even adding that this had been her reason for leaving, the leadership either toned it down or denied it altogether. By then, talking about sacrifice and "sought suffering" had already become so alien, awkward and uncomfortable that it had been erased from history. ${ }^{21}$

18 Gertie Lauscher, De graankorrel in de aarde (not published, 1970); 50 jaar Graal, 1921-1971. Verleden, heden, toekomst (not published, 1971).

19 Lydwine van Kersbergen, "De Graal: een katholieke jonge-vrouwenbeweging," Het Binnenhof (14 mei 1991).

20 Ine van Emmerik, ed., Gevaarlijk modern. Levende geschiedenissen van vrouwen in de Graalbeweging (not published, 2001).

21 Hilde van Oostrum, Documentary in two parts. Part 1: K(l)eurig, kwiek en katholiek; part 2: Hé, is dat mijn moeder? (1982). See http://www.filmfestival.nl/industry/films/ kleurig-kwiek-en-katholiek-de-graal. 


\subsection{Welcome and Unwelcome Heritages}

The meaning and valuation of the concepts of sacrifice and, consequently, of personal suffering varies throughout history. Sacrifice and suffering are also highly gendered notions. This becomes apparent when we look at two distinct periods in Dutch modern history (the interwar era and the post-Vatican era) in which the Grail evolved from a Catholic conversion movement into a feminist theological religious group.

In the 1920s and 1930s, the ritual and personal meaning of sacrifice and of both personal and communal suffering was vital for the self-understanding of the Grail members. They were influenced by converts like Jacques and Raïssa Maritain and their entourage, and by a widespread revival in the western world of 'victim-souls', people who indulged in physical and mental suffering in the imitation of Christ. Incited and controlled by their founder and spiritual leader, Father Jacques van Ginneken sJ, the intellectual women of the Grail movement cultivated personal and communal sacrifice, both within their own ranks and in the thousands of young girls that they gathered and guided in a girls' movement. They saw the capacity for suffering, in particular suffering for religious reasons, as the most outstanding female quality. In this way, Catholic femininity was heroically and romantically equated with conversion and sacrifice.

This specific historical example sheds light on the confusing character that religious sacrifice held for women. While its overall spirituality referred to the suffering of Christ, and offered women a way to become co-saviors, in practice it did much more than that. It ambiguously spelled both the shaping of a collective purpose and the creation of hierarchy. While being directed at submission to the will of God, it also provided means for individual human excellence. Last but not least, these practices served as a disciplinary instrument on various levels, thus pointing at sacrifice as a source of repression.

That the meaning of sacrifice is basically historical became obvious through the transformation of the culture of sacrifice from the 196os onwards, when, under the influence of both the Second Vatican Council and the feminist movement, it became a contested concept. A new generation of Grail members sought female heroism in personal spiritual transformation, while both sacrifice and conversion were first frowned upon and later disappeared altogether from their vocabulary. While trying to reinvent their past and their tradition, they radically erased all notions of sacrifice and suffering from their collective memory, replacing them with feminist concepts of assertiveness. To a large extent, the same process took shape in many female religious orders the same from which the Grail movement so explicitly wanted to differ. In the aftermath of Vatican II they, too, distanced themselves from sacrifice and suf- 
fering and from other aspects of their history. ${ }^{22}$ The idea of the proud suffering Catholic woman, as well as that of the strict male leader that supported her, had become unwelcome heritages that disappeared from memory and therefore from history.

22 This process has been eloquently described in Annelies van Heijst, Models of Charitable Care. Catholic Nuns and Children in their Care in Amsterdam, 1852-2002 (Leiden: Brill, 2008), 301-350. 